\title{
Pharmacognosy \\ Non-polar extracts of Nicotiana glauca (Solanaceae) induce apoptosis in human rhabdomyosarcoma cells
}

\author{
Florencia Musso $^{1}$, Lucía Pronsato ${ }^{2}$, Lorena Milanesi ${ }^{2}$, Andrea Vasconsuelo ${ }^{2}$ \& María Belén Faraoni ${ }^{1,3,4}$
}

\begin{abstract}
Rhabdomyosarcoma (RMS) is the most common soft-tissue tumour in children and adolescents. It originates in normal skeletal muscle from myogenic cells that have failed to fully differentiate, and it usually has a poor prognosis. Current RMS therapy has many adverse effects. Hence, new treatments are needed. Various pharmacological properties, such as analgesic, antineoplastic, antimicrobial, and antiparasitic properties, have been demonstrated in species of the Solanaceae family. We performed ethanolic extraction from leaves of Nicotiana glauca (Solanaceae), and the extract was successively partitioned with $n$-hexane, chloroform, and ethyl acetate. We evaluated the effects of extracts on RMS cells, and we found that the extracts trigger apoptosis. By bio-guided fractionation assays, we identified the apoptotic agents. Morphological assessment after apoptotic cell induction of cultured cells, mitochondrial and nuclear morphology by Mitotracker, and 4,6-diamidino-2-phenylindole (DAPI) staining, respectively, were analysed in fluorescent microscopy. The capacity of the cells to migrate or proliferate was analysed by the Petit assay, followed by methylene blue staining. NMR and GC-MS spectrometry were used to identify palmitic acid and scopoletin as the phytochemicals responsible for the observed effects. These results indicate that these compounds are apoptotic inducers and they could be useful as chemotherapeutic agents against muscle tumours.
\end{abstract}

Key words: apoptosis, Nicotiana glauca, palmitic acid, Rhabdomyosarcoma, Scopoletin.

\section{Resumo}

Rabdomiossarcoma (RMS) é o tumor de tecidos moles mais comum em crianças e adolescentes. Ele se origina no músculo esquelético normal a partir das células miogênicas que não conseguiram-se diferenciar completamente e pelo geral tem um prognóstico ruim. A terapia atual com RMS tem muitos efeitos adversos e portanto, novos tratamentos são necessários. Várias propriedades farmacológicas, como propriedades analgésica, antineoplásica, antimicrobiana e antiparasitária, foram demonstradas em espécies da família Solanaceae. Neste trabalho, foi realizada a extração etanólica das folhas de Nicotiana glauca (Solanaceae), e o extrato foi particionado sucessivamente com $n$-hexano, clorofórmio e acetato de etila. Avaliamos os efeitos dos extratos nas células RMS e descobrimos que os extratos desencadeiam apoptose. Pelos ensaios de fracionamento bio-guiado, identificamos os agentes apoptóticos. A avaliação morfológica após indução da apoptose das células cultivadas e a morfologia mitocondrial e nuclear por coloração com Mitotracker e 4,6-diamidino-2-fenilindol (DAPI), respectivamente, foram analisadas com microscopia fluorescente. A capacidade das células para migrar ou proliferar foi analisada pelo ensaio Petit, seguido pelacoloração com azul de metileno. A espectrometria de RMN e GC-MS foi utilizada para a identificação o ácido palmítico e a escopoletina como os fitoquímicos responsáveis pelos efeitos observados. Estes resultados indicam que estes compostos são indutores apoptóticos e poderiam ser úteis como agentes quimioterapêuticos contra tumores musculares.

Palavras-chave: apoptose, Nicotiana glauca, ácido palmítico, Rabdomiossarcoma, Escopoletina.

\footnotetext{
${ }^{1}$ Universidad Nacional del Sur - CONICET, Inst. Química del Sur (INQUISUR), Av. Alem 1253, Bahía Blanca, Argentina.

${ }^{2}$ Universidad Nacional del Sur - CONICET, Inst. Ciencias Biológicas y Biomédicas del Sur (INBIOSUR), San Juan 671, Bahía Blanca, Argentina.

${ }^{3}$ ORCID: <https://orcid.org/0000-0002-9940-3613>

${ }^{4}$ Author for correspondence: bfaraoni@criba.edu.ar
} 


\section{Introduction}

Rhabdomyosarcoma (RMS) is the most common soft-tissue tumour in children and adolescents. This aggressive childhood cancer originates in normal skeletal muscle from myogenic cells that have failed to fully differentiate (Hettmer $\&$ Wagers 2010). RMS can appear in any site on the body, but it is primarily found in the head, neck, orbit, genitourinary tract, genitals, and extremities. It represents $3.5 \%$ of cancer cases in children from 0 to 14 years and $2 \%$ in adolescents and young adults from 15 to 19 years (Young et al. 1986; Ognjanovic et al. 2009). The treatment of RMS is a multidisciplinary practice that involves the use of surgery, chemotherapy, and radiotherapy or combined modality therapy (Donaldson et al. 2001, 2005; Stevens et al. 2005). With the administration of chemotherapeutic drugs, several side effects appear, and this is aggravated by the fact that the patients are very young. Radiotherapy is indicated for control of the disease in $90 \%$ of the cases, but in paediatric patients ionizing radiation alters its growth and development, as well as the potential risk of suffering a secondary neoplasm (Berenman $\&$ Wiener 2000). On the other hand, high doses of radiation are required in the tumour, which must be balanced with the need to minimize the doses in normal tissue (Gunderson et al. 2000).

In addition to the adverse effects attributed to current therapy, late effects may also appear. Therefore, this type of cancer usually has a poor prognosis, especially post-metastasis (Malempati \& Hawkins 2012). Currently, the need for new treatments is emphasized, aimed at minimizing the long-term impact of therapy and improving the quality of life of the children.

Since ancient times, natural products isolated from medicinal plants have been used for the treatment of various diseases (Dutta et al. 2019; Mansoori et al. 2019). Recently, investigations have shown that plant extracts, including tumourtargeting compounds, can be used in numerous cancer treatments. Specifically, the use of plant extracts has shown effectiveness by abrogating cancer initiation, development, and progression, as well as interrupting several mechanisms, such as differentiation, cellular proliferation, angiogenesis, apoptosis, and metastasis (Mukherjee et al. 2001; Ouyang et al. 2014). The use of these natural compounds instead of synthetic chemotherapeutic drugs is an alternative since they are environmentally sustainable and lack important side effects.
The Solanaceae family has more than 90 genera and nearly 3,000 species distributed throughout the world, with a great diversity of habitats, morphology, and ecology. It is present on all continents except Antarctica. The greatest diversity of species is found in South America and Central America. Medicinally important species of the Solanaceae family belong to the following genera, namely Solanum, Atropa, Capsicum, Datura, Withania, Hyoscyamus, Nicotiana, and others. Solanaceae are widely used by humans, and they are an important source of food, ornamentation, spice, and medicine (Shah et al. 2013; Yadav et al. 2016). In addition, various pharmacological properties have been demonstrated in species of this family, such as analgesic, antineoplastic, hypoglycemic, antimicrobial, and antiparasitic properties (Torres-Nagera et al. 2013).

Nicotiana glauca Graham (Solanaceae) is widely distributed in Argentina, and it is considered as an undergrowth due to its abundance and geographic distribution (Falasca \& Ulberich 2011). The local name in South America is palán-palán. Based on ethnic and cultural uses, its leaves have been used to treat swellings, boils, jaundice, headaches, rheumatism, and wounds (Janakat \& Al-Merie 2002). Previously, we found that lipidic extracts from $N$. glauca induced apoptosis in $\mathrm{C} 2 \mathrm{C} 12$ cells (Musso et al. 2019). Since these cells are myogenic, it was hypothesized that these extracts would also have an antiproliferative/ apoptotic effect in RMS since the origin of RMS is linked to a defect in myogenic cells. Thus, the goal of this study was to investigate the antiproliferative/apoptotic potential of $N$. glauca extracts on human embryonic RMS cells by bioguided fractionation assays. Finally, we elucidated the main phytochemicals responsible for the observed effects.

\section{Materials and Methods}

All reagents used were of analytical grade. MitoTracker (MTT) (MitoTracker ${ }^{\circledR}$ Red CMXRos) and DAPI (4',6-diamidino-2-phenylindole) dyes were from Molecular Probes (Eugene, OR, USA). For column chromatography, 70-230 (Merck), and 200-425 mesh (Aldrich) silica gel 60 were used. The chromatographies were monitored by TLC on silica gel plates (60F-254), visualized under UV light and/or using $p$-anisaldehyde-acetic acid in ethanol spray reagent. NMR experiments were carried on a Bruker ARX 300 spectrometer. Palmitic acid (PA) and scopoletin were registered 
in deuterated chloroform $\left(\mathrm{CDCl}_{3}, 99.8 \% \mathrm{D}\right.$, Aldrich). Chemical shifts $(\delta)$ are reported in ppm from tetramethylsilane (TMS) using the residual solvent resonance $\left(\mathrm{CDCl}_{3}: 7.26 \mathrm{ppm}\right.$ for ${ }^{1} \mathrm{H}-\mathrm{NMR}$ and $77.16 \mathrm{ppm}$ for ${ }^{13} \mathrm{C}-\mathrm{NMR}$. Multiplicities are abbreviated as follows: $\mathrm{s}=$ singlet; $\mathrm{d}=$ doublet; $\mathrm{t}=$ triplet; $\mathrm{m}=$ multiplet; br $\mathrm{s}=$ broad signal). Melting points were determined using a Büchi 510 apparatus and are not corrected. Mass spectra were obtained at $70 \mathrm{eV}$ on an Agilent GC-78903 instrument with a MS-5977 A MSD selective mass detector.

\section{Plant material}

Nicotiana glauca plant specimens were collected from their natural habitat in Bahía Blanca, Buenos Aires, Argentina and were grown under greenhouse conditions. Plant specimens were identified by comparison with the Carlos Villamil herbarium specimen ( $\mathrm{N}^{\circ}$ 9348). It is found in the Herbarium of the Department of Biology, Biochemistry, and Pharmacy (BBB), Universidad Nacional del Sur, $(8,000)$ Bahía Blanca, Argentina. Plant name was checked with the online website of The International Plant Name Index (IPNI), $<$ https://www.ipni.org>, accessed in May 2019. An herbarium voucher specimen was kept at the Herbarium of the Department of Biology, Biochemistry and Pharmacy (BBB), Universidad Nacional del Sur.

\section{Extraction of lipid extracts}

The starting plant material was from leaves of N. glauca (126 g), which was extracted twice with $96 \%$ ethanol at room temperature for 10 days. The ethanolic extract (crude extract) was concentrated under reduced pressure, giving $26.3 \mathrm{~g}(21 \%) ; 4 \mathrm{~g}$ (non-lyophilized) of this residue was successively partitioned with $n$-hexane, chloroform, and ethyl acetate. The extracted solutions were evaporated under reduced pressure and then lyophilized to yield $993 \mathrm{mg}(24.8 \%)$ of $n$-hexane sub-extract, 28 $\mathrm{mg}(0.7 \%)$ of chloroform sub-extract, and $164 \mathrm{mg}$ (4.1\%) ethyl acetate sub-extract. Of the three subextracts, the $n$-hexane and chloroform sub-extracts had the highest apoptotic effects in myogenic skeletal muscle C2C12 cells (Musso et al. 2019); therefore, these were selected for further separation. Chromatography on silica gel of $n$-hexane subextract, eluted with $n$-hexane/ethyl acetate (100:0 to $0: 100$, step-gradient system), yielded five fractions (F1-F5). Of these fractions, F3 (66.4 $\mathrm{mg}$ ) was subjected to flash chromatography, eluted with $n$-hexane/ethyl acetate (100:0 to 90:10, stepgradient system), yielding three sub-fractions (SF1-SF3), of which the sub-fraction SF1 led to obtaining PA in pure form as a white solid $(6.4 \mathrm{mg}$, $0.033 \%$ from the material plant, $\mathrm{mp}=63{ }^{\circ} \mathrm{C}$ ). The structure of PA was confirmed by NMR and GC-MS spectrometry. ${ }^{1} \mathrm{H}-\mathrm{NMR}$ and ${ }^{13} \mathrm{C}-\mathrm{NMR}$ data were in agreement with previously reported findings (Bordoloi et al. 2017; Zhao et al. 2017). ${ }^{1} \mathrm{H}-\mathrm{NMR}$ $\left(300 \mathrm{MHz}, \mathrm{CDCl}_{3}\right): \delta$ (ppm) 2.34 (t, J $=7.1 \mathrm{~Hz}$, $2 \mathrm{H}), 1.63(\mathrm{~m}, 2 \mathrm{H}), 1.25(\mathrm{br} \mathrm{s}, 24 \mathrm{H}), 0.87(\mathrm{t}, \mathrm{J}=$ $7.1 \mathrm{~Hz}, 3 \mathrm{H}) ;{ }^{13} \mathrm{C}-\mathrm{NMR}(75 \mathrm{MHz}, \mathrm{CDCl} 3): \delta(\mathrm{ppm})$ $178.97,33.97,32.08,29.85,29.74,29.58,29.51$, 29.39, 29.21, 24.84, 22.84, 14.26; MS (EI, $70 \mathrm{eV}$ ) $\mathrm{m} / \mathrm{z}$ at $256.3[\mathrm{M}]^{+}, 213.2,157.1,129.1,97.1,73.1$.

Chromatography on silica gel of the chloroform sub-extract, eluted with $n$-hexane/ ethyl acetate (100:0 to 0:100, step-gradient system), yielded five fractions (F1-F5). Of these fractions, F5 (24 mg) was subjected to flash chromatography, eluted with dichloromethane/methanol (100:0 to $0: 100$, step-gradient system), yielding five subfractions (SF1-SF5), of which sub-fraction SF2 was chromatographed by preparative TLC using dichloromethane-methanol $(95: 5)$ as the mobile phase. This led to us obtaining scopoletin in pure form as a yellowish solid $(1.1 \mathrm{mg}, 0.006 \%$ from the material plant, $\mathrm{mp}=204^{\circ} \mathrm{C}$ ). This yield is similar to that reported by Tabana et al. (2016), who used the stems of $N$. glauca as plant material. The structure of scopoletin was confirmed by NMR and GC-MS spectrometry. ${ }^{1} \mathrm{H}-\mathrm{NMR}$ and ${ }^{13} \mathrm{C}-\mathrm{NMR}$ data were in agreement with previously reported findings (Khan \& Hossain 2015; Tabana et al. 2016). ${ }^{1} \mathrm{H}-\mathrm{NMR}$ $\left(300 \mathrm{MHz}, \mathrm{CDCl}_{3}\right): \delta(\mathrm{ppm}) 7.59(\mathrm{~d}, \mathrm{~J}=9.5 \mathrm{~Hz}$, $1 \mathrm{H}), 6.92(\mathrm{~s}, 1 \mathrm{H}), 6.85(\mathrm{~s}, 1 \mathrm{H}), 6.27(\mathrm{~d}, \mathrm{~J}=9.2 \mathrm{~Hz}$, 1H), 6.14 (br s, 1H, -OH), 3.96 (s, 3H); ${ }^{13} \mathrm{C}-\mathrm{NMR}$ $\left(75 \mathrm{MHz}, \mathrm{CDCl}_{3}\right): \delta$ (ppm) 161.56, 150.42, 149.82, 144.12, 143.42, 113.60, 111.65, 107.63, 103.34, 56.57; MS (EI, $70 \mathrm{eV}) \mathrm{m} / \mathrm{z}$ at $192.0[\mathrm{M}]^{+}, 177.0$, 164.0, 149.0, 121.0, 82.0, 41.0 .

The final residue of each phase was solubilized in isopropanol $(60 \mu \mathrm{L})$ and stored at $-20^{\circ} \mathrm{C}$.

\section{Cell cultures}

The RD cell line (CCL-136 $\left.{ }^{\mathrm{TM}}\right)$, American Type Culture Collection (ATCC ${ }^{\circledR}$ ), consisted of rhabdomyosarcoma cells from a 7-year-old Caucasian girl. Morphology: spindle and large adherent with some multinucleated cells, virus susceptibility, unstable within a hyper diploid bimodal stem line number of 49 and 50. RD were cultured in growth medium (Dulbecco's modified 
Eagle's medium) supplemented with $10 \%$ heatinactivated $\left(30 \mathrm{~min}, 56{ }^{\circ} \mathrm{C}\right)$ fetal bovine serum, $1 \%$ nystatin, and $2 \%$ streptomycin. Cells were incubated at $37{ }^{\circ} \mathrm{C}$ in a humid atmosphere of $5 \%$ $\mathrm{CO}_{2}$ in air. Cultures were passaged every 2 days with fresh medium. Cells were cultured in $3 \mathrm{~cm}$ and $6 \mathrm{~cm}$ plates for microscopy or in $10 \mathrm{~cm}$ plates for migration/proliferation assays (Greiner Bio-One, Frickenhausen, Germany).

Treatments were performed with $70-80 \%$ confluent cultures $\left(120,000 \mathrm{cells} / \mathrm{cm}^{2}\right)$ in medium without serum. Since the origin of RD is a disruption in the regulation of growth and differentiation of cells during myogenesis (Hettmer \& Wagers 2010), this led us to think that the RD cell line would be sensitive to the extracts since the myogenic skeletal muscle $\mathrm{C} 2 \mathrm{C} 12$ cells are (Musso et al. 2019). The concentrations used in each experiment were previously established (Musso et al. 2019). The ethanolic extract, $n$-hexane and chloroform sub-extracts, PA, and scopoletin were dissolved at $2.5 \mathrm{mg} / 5 \mathrm{~mL}$ isopropanol, and the cells were then exposed to the different treatments [1:1000 dilution in DMEM without serum; ethanolic extract from $N$. glauca, $n$-hexane and chloroform sub-extracts, PA, scopoletin, or vehicle $(0.001 \%$ isopropanol, control)] at the times indicated in each assay.

\section{Cell migration/proliferation assay}

The effect of the different treatments on cell migration/proliferation was studied by the Petit assay (Petit et al. 2000). Cells were grown in $10 \mathrm{~cm}$ plates up to $70 \%$ confluence, and then, with a sterile tip, a wound with the form of a cross was made in each plate, exposing a section of the cell monolayer. Cells were exposed to the different treatments for 2 hours. After the different treatments, the medium was changed to new media without serum, and the central area of the wound was observed under a conventional microscope at different times. Images were collected immediately at the end of the treatments (hour 0) and at 3 hours (migration) and 24 hours (proliferation). After 48 hours, the cells were stained with methylene blue. The solution of this substance is blue in an oxidizing environment, but it will turn colourless if exposed to a reducing medium. Living cells contain enzymes capable of reducing the methylene blue to a colourless compound. The dye enters the living cell and is reduced by redox activity. In dead or apoptotic cells, enzyme activity is avoided or diminished, respectively. Therefore, methylene blue cannot be reduced, and cells maintain the blue colour.
Morphological assessment of cultured cells by bright field microscopy

This analysis has been used to monitor the cellular changes induced by apoptosis (Taatjes et al. 2008). The RD cell line was grown in $6 \mathrm{~cm}$ plates until 60/70\% confluence in DMEM medium and observed at time 0 (before the treatment). It was then exposed to PA and scopoletin during 2 hours and observed the same field after the different treatments, as it was described previously. Images were collected with a light microscope, and timelapse recording was done with a CCD camera connected to a computer (Using NIS-Element Basic Research Program Ver. 2.35 of NIKON).

\section{Mitochondrial and nuclear morphology after apoptotic cell induction}

After the different treatments, mitochondrial and nuclear morphology/distribution were observed in the RD cell line; growing in $3 \mathrm{~cm}$ plates with coverslips; employing the selective stain MTT dye for active mitochondria, and DAPI dye for the nucleus selective stain. Coverslips with adherent cells were stained with MTT, which was prepared in dimethyl sulfoxide (DMSO) and then added to the cell culture medium at a final concentration of $1 \mu \mathrm{mol} / \mathrm{L}$ in PBS $1 \times$. After 15 to 30 min incubation at $37^{\circ} \mathrm{C}$, the cells were washed with PBS $1 \mathrm{X}$, fixed and permeabilized with methanol at $-20{ }^{\circ} \mathrm{C}$ for $30 \mathrm{~min}$. Fixed cells were incubated for $30 \mathrm{~min}$ at RT in darkness with 1:500 dilution of DAPI (5 $\mathrm{mg} / \mathrm{mL}$ ). Finally, the coverslips were mounted on glass slides and examined using a fluorescence microscope (NIKON Eclipse Ti-S) equipped with standard filter sets to capture fluorescent signals. The images were collected using a digital camera.

\section{Results}

Figure 1 shows the scheme of the bio-guided fractionation of the ethanolic extract of $N$. glauca and the successive chromatographies that lead to the isolation of PA and scopoletin.

The starting plant material was from leaves of $N$. glauca, which was extracted with $96 \%$ ethanol at room temperature for 10 days. Then, it was successively partitioned with $n$-hexane, chloroform, and ethyl acetate. The capacity to induce apoptosis was analysed in each sub-extract using MTT and DAPI staining, which determined mitochondrial and nuclear morphology, observing lower cellular viability for the $n$-hexane and 


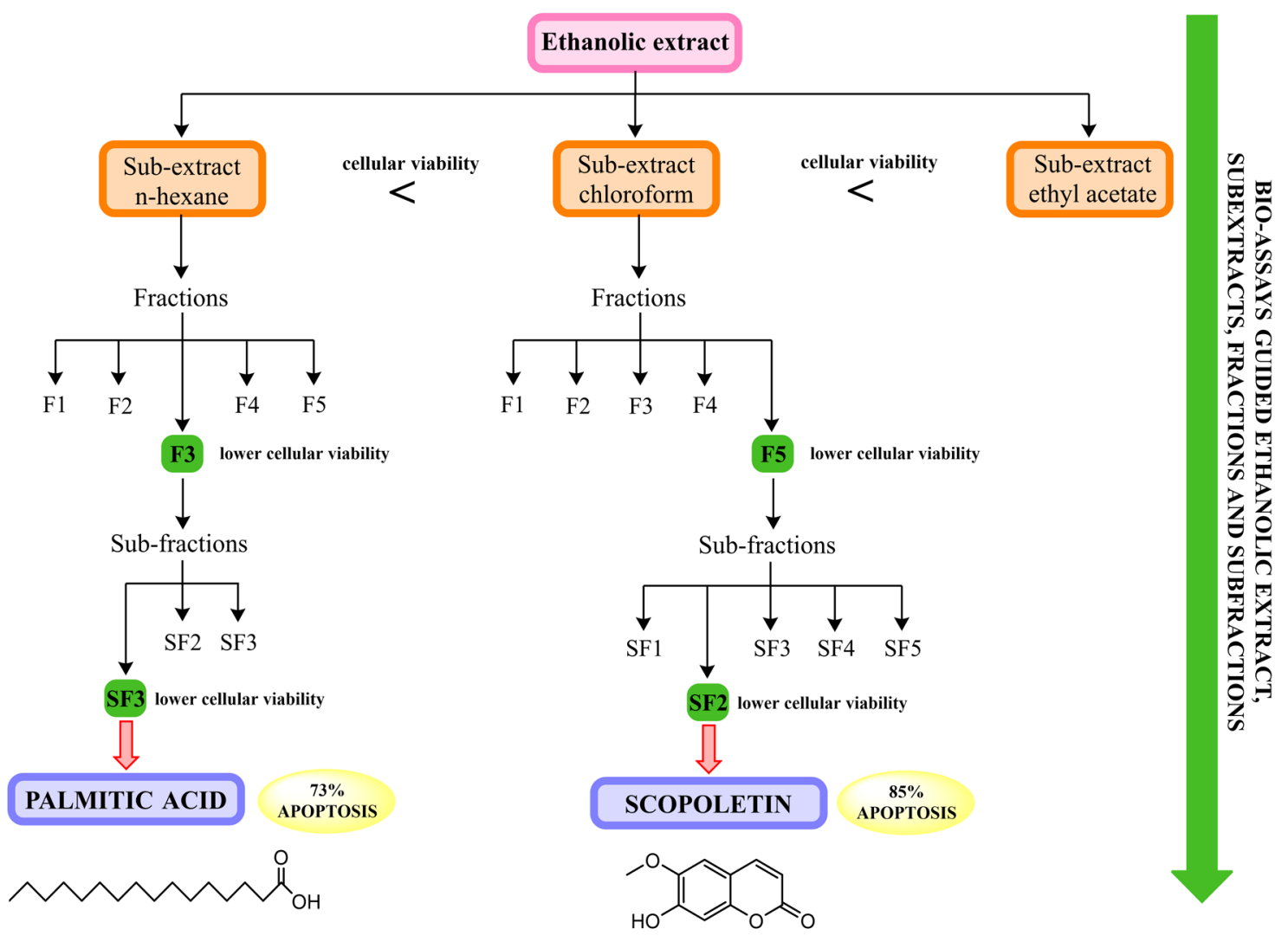

Figure 1 - Scheme of the bioguided fractionation of the ethanolic extract of Nicotiana glauca and the successive chromatographies that lead to the isolation of palmitic acid and scopoletin.

chloroform sub-extracts. Thus, they were selected for further separation by chromatography. From the $n$-hexane sub-extract, five fractions (F1-F5) were obtained. Again, the capacity to induce apoptosis was analysed in the different fractions to select the fraction with the lowest cellular viability (F3). This fraction was subjected to chromatography, yielding three sub-fractions (SF1-SF3), of which the subfraction SF1 was the most apoptotic. This subfraction led to us obtaining PA in pure form. The structure of PA was confirmed by NMR and GC-MS spectrometry.

Chromatography of the chloroform subextract yielded five fractions (F1-F5). Again, the fractions were analysed for apoptosis to select the fraction with lowest cellular viability (F5). This fraction was subjected to chromatography, yielding five sub-fractions (SF1-SF5), of which the subfraction SF2 was the most apoptotic. This subfraction led to us obtaining scopoletin in pure form. The structure of scopoletin was confirmed by NMR and GC-MS spectrometry.
In the RD cell line, we first evaluated the effects of the different treatments on two cellular processes. To this end, we began studying the influence of the extracts and phytochemicals obtained from these on proliferation and migration (the last one is related to one of the metastasis processes) by the Petit assay (Petit et al. 2000). After the different treatments, the medium was changed to new media without serum, and the central area of the wound was observed under a conventional microscope at different times [hour 0 (Fig. 2a), 3 hours (migration, Fig. 2b), and 24 hours (proliferation, Fig. 2c)]. PA and scopoletin treatments reduced proliferation and resulted in no migration (Fig. 2b,c). Also, scopoletin showed greater capacity than PA to reduce cell proliferation. In both treatments, apoptotic and death cells were observed during the first 3 hours until the end of the assay ( 48 hours). RD cells treated with the ethanolic extract or $n$-hexane sub-extract showed not only loss of proliferation but also apoptosis in all cell populations. No cells were observed 24 hours after these treatments (Fig. 2c). 


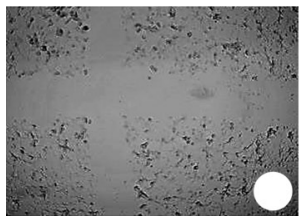

Control

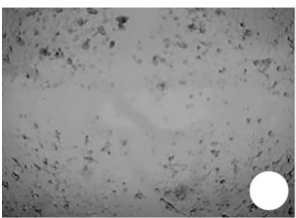

Control

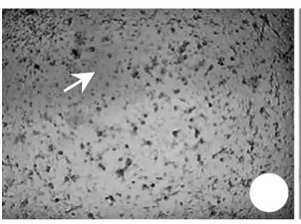

Control

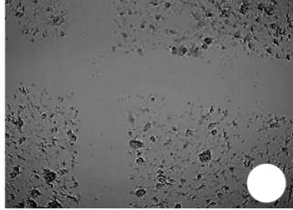

Ethanolic extract

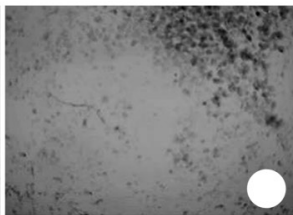

Ethanolic extract

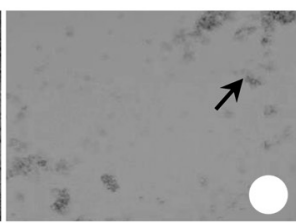

Ethanolic extract

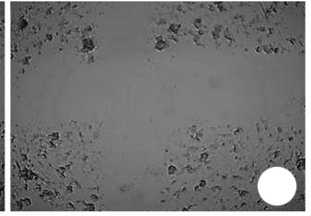

$n$-hexane sub-extract

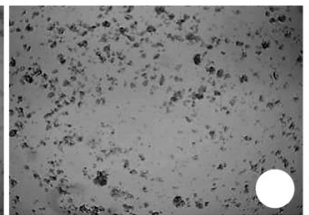

$n$-hexane sub-extract

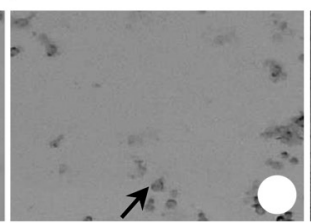

$n$-hexane sub-extract

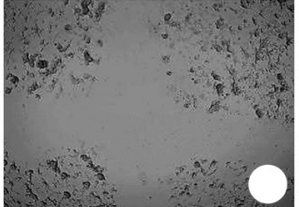

Palmitic acid

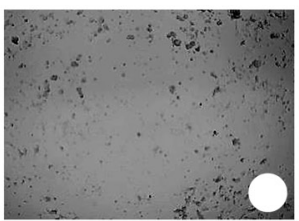

Palmitic acid

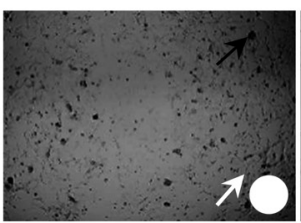

Palmitic acid

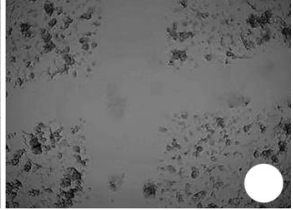

Scopoletin

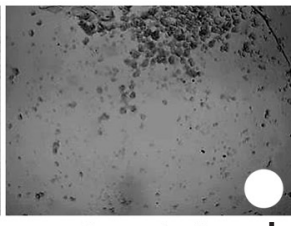

Scopoletin b

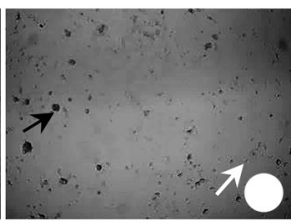

Scopoletin

Figure 2 - a-c. Cell migration and proliferation is abolished or diminished by the different treatments. After the different treatments (Methods), cells were observed at different periods of time for 24 hours - a. hour 0; b. 3 hours; c. 24 hours. White arrows show cells that survive and proliferate after the different treatments. Black arrows show dead cells that lose adherence and form cell clusters. Representative photographs are shown. Original magnification: $4 \times$.

After 48 hours, the cells were stained with methylene blue. The solution of this substance is blue in an oxidizing environment, but it will turn colourless if it is exposed to a reducing environment. Living cells contain enzymes capable of reducing the methylene blue to a colourless compound. The dye enters the living cell and is reduced by redox activity. In dead cells or in apoptotic cells, enzyme activity is avoided or is diminished, respectively. Therefore, methylene blue cannot be reduced, and cells maintain the blue colour. Staining with methylene blue clearly shows a significant number of dead or apoptotic cells that are still adhered in PA and scopoletin treatments. In the ethanolic extract or the $n$-hexane sub-extract treatment, no cells were observed (the cells died, tearing of the monolayer) (Fig. 3).

Morphological assessment of cultured cells by bright field microscopy has been used to monitor the cellular changes induced by apoptosis (Taatjes et al. 2008). Here, the RD cells were treated with $\mathrm{PA}$, as indicated in the Methods section, then imaged with a light microscope, and time-lapse recording was done with a CCD camera connected to a computer. Figure 4 shows the same field of cells at time 0 (before the treatment) and after 2 hours of PA treatment. Clearly, the images display the changes in morphology, size, and distribution of mitochondria. At time 0 , the cells present a uniform distribution of mitochondria through the cytosol. On the other hand, 2 hours after PA treatment the cells showed reduced size and 'pyknotic' mitochondria, with a characteristic clustering of the organelle around the nucleus (which represented near $70 \%$ of the cultured cells), suggesting that $\mathrm{PA}$ is able to trigger apoptosis in RD. Changes in mitochondrial distribution and nuclear morphology are classic events that occur early during the apoptotic induction. When the RD cells were treated with scopoletin, similar results were observed, which represented nearly $85 \%$ of the cultured cells (images not shown). In Figure 5, after the different treatments, cells were stained with the fluorescent mitochondrial probe MitoTracker Red, then fixed, permeabilized, and stained with the nuclear dye DAPI, as described in the Methods section. Mitochondrial morphology, distribution, and nuclear morphology were observed under conventional fluorescent microscopy. Analysis of fluorescence-staining is shown in Figure 5. In control cells (untreated RD cells), normal mitochondrial morphology and distribution was observed. RD cells displayed a "spider-web" or uniform mitochondrial pattern through the 


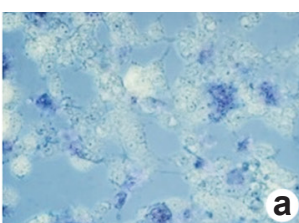

Control

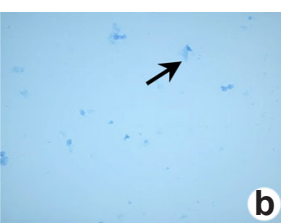

Ethanolic

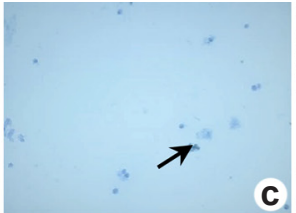

n-hexane sub-

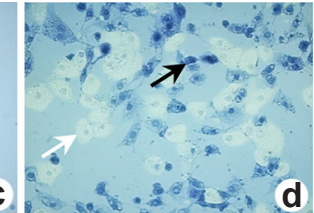

Palmitic acid

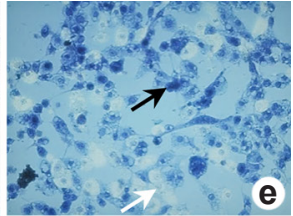

Scopoletin

Figure 3 - Methylene blue staining. After 48 hours of the Petit assay, cells were stained with methylene blue (Methods). White arrows show living cells, and black arrows show apoptotic or dead cells that still are adherent. Representative photographs are shown. Original magnification: $20 \times$.

cytosol and a normal nuclear morphology (Fig. 5a). In apoptotic cells (Fig. 5b-d), an atypical mitochondrial distribution (loss of the "spider web" form) and reduced mitochondrial size, with a characteristic clustering of the organelle close to the nucleus, was observed, resulting in more intense fluorescence over the nucleus. This atypical distribution is observed surrounding a pyknotic nucleus with a condensed chromatin.

\section{Discussion}

The treatments of RD cells with extracts, fractions, and phytochemicals from N. glauca, significantly reduced the cellular capacity to proliferate and migrate, classical conducts during metastasis. Also, apoptosis and cell death were induced. They were demonstrated not only by their morphological changes but also by the particular distribution of the mitochondria surrounding a pyknotic nucleus, although the molecular mechanisms underlying these changes have not been fully elucidated. Several interpretations may apply regarding the physiological relevance of the redistribution of the organelle in response to this treatment. Some authors suggest that the clustering of mitochondria surrounding the nuclear region could be a defence response that improves the signalling between mitochondria and nucleus. Regardless, changes in mitochondrial distribution is clearly associated with modifications in cytoskeleton architecture during apoptosis. Also, translocation of the organelle could facilitate the travel of mitochondrial components, such as apoptosis-inducing factor (AIF), which binds to DNA and triggers its destruction (Susin et al. 2000). Moreover, the modifications that undergo mitochondria-like size reduction or pyknosis could be related to the release of mitochondrial proteins (e.g., AIF, cytochrome c) observed during apoptotic death (Granville et al. 2001). As mentioned before, these morphological changes imply the participation of the cytoskeleton, but more studies

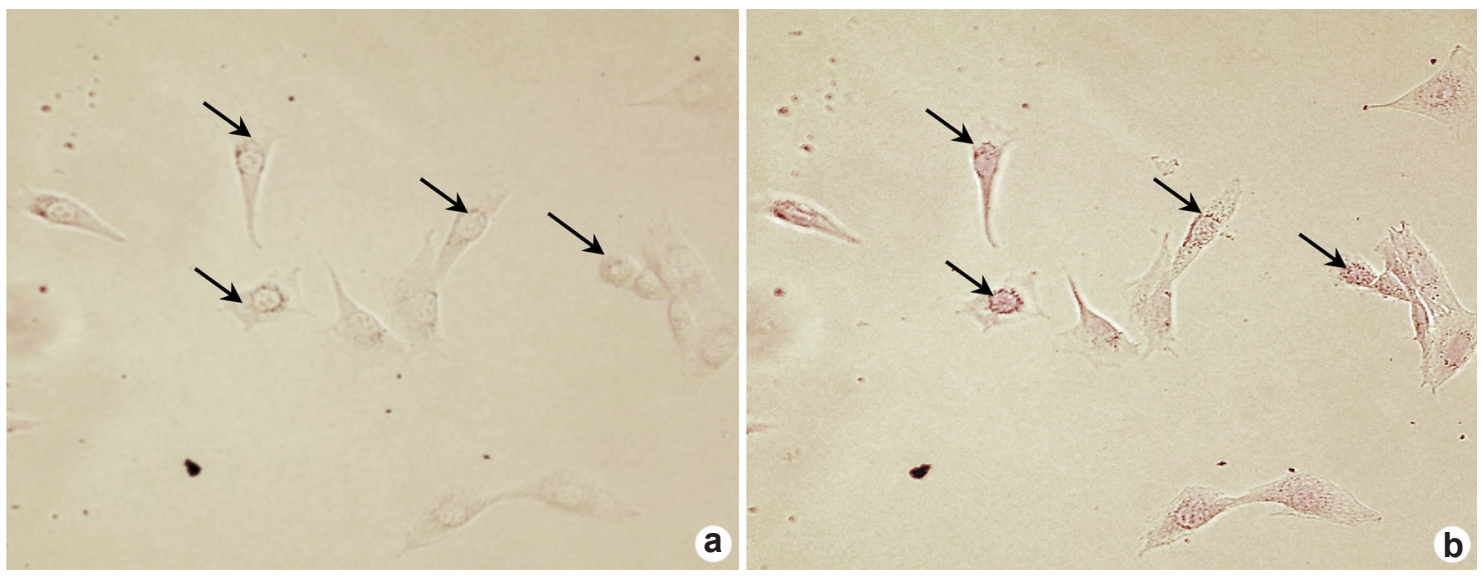

Figure 4-a-b. Change in mitochondrial size and distribution observed with bright field microscopy. Changes in size and distribution of mitochondria - a. hour 0 , uniform distribution of mitochondria through the cytosol; b. 2 hours after palmitic acid treatment, $70 \%$ of the cultured cells showed reduced size 'pyknotic' mitochondria and clustering of the organelle around the nucleus. Representative photographs are shown. Original magnification: $60 \times$. 


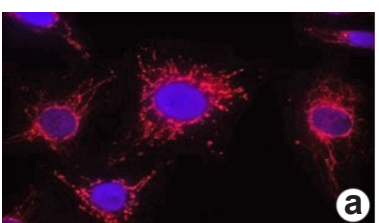

Control

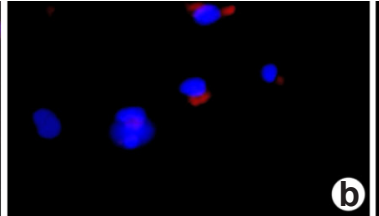

Ethanolic

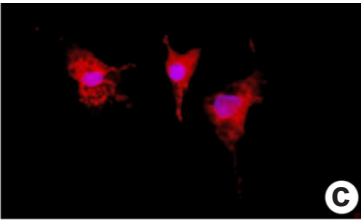

Palmitic acid

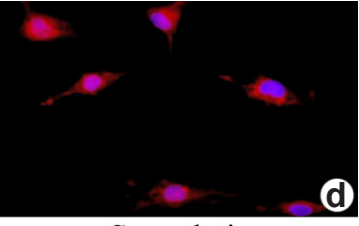

Scopoletin

Figure 5 - a-d. Apoptotic induction by the ethanolic extract, palmitic acid and scopoletin, derived from N. glauca, in RD cell line. Morphological analysis of fluorescence-stained nuclei is shown - a. control (untreated RD cells) with normal mitochondrial morphology and distribution (throughout the entire cell, distant to the nucleus and normal nuclear morphology); b-d. apoptotic cells with atypical mitochondrial distribution, surrounding a pyknotic nuclei. Representative photographs are shown. Original magnification: $60 \times$.

are necessary to understand the molecular events that underlie this cellular response.

The results obtained here agree with previously published literature, which indicates that PA and scopoletin are apoptotic inducers. PA induces toxicity and apoptosis, and multiple pathways could be involved (Park et al. 2014). In neural stem cells, Yuan et al. (2013) observed that elevated plasma free fatty acids (FFAs) level is common in many pathological conditions, including neurological disorders, and their deleterious effects on various cells have been well documented. They reported that PA impaired cell viability and increased apoptosis of neural stem cells significantly in a dose- and time-dependent manner. On the other hand, they observed that PA apoptotic induction involved the c-Jun N-Terminal Kinase (JNK) activity (Yuan et al. 2013). Likely, some unsaturated FFAs, such as arachidonic acid, linoleic acid and linolenic acid, have been reported to play a key role in injuries of fatty liver through direct cytotoxicity (Ji et al. 2005). These authors observed, in HepG2 cells (human hepatocarcinoma cell line) that PA induces apoptosis, probably via mitochondria intrinsic pathway. PA inhibited cell growth in a dose and time-dependent manner, and induced morphological changes including swelling and membrane dissolution. Levels of the antiapoptotic protein Bcl-2 (B cell lymphoma) were slightly decreased, in contrast to the levels of Bax (Bcl-2-like protein) apoptotic protein, resulting in a significant decrease of Bcl-2/Bax ratio after treatment. Recently, has been shown that several coumarin-type compounds have been reported to exhibit anti-angiogenic properties. Scopoletin, a 6-methoxy-7-hydroxycoumarin, may have antiangiogenic potential. To document this hypothesis, studies were performed to test the effects of scopoletin on angiogenesis. Pan et al. (2009) observed that scopoletin had no cytotoxic effect on endothelial cells at the concentrations tested but suppressed the endothelial cell migration and disrupted rat tail collagen tube formation at specific $\mathrm{mM}$ concentrations whereas it only moderately inhibited the proliferation and cell adhesion, but selectively downregulated serum-induced extracellular signal-regulated protein kinases 1 and 2 (ERK1/2) phosphorylation, without affecting p38 mitogen-activated protein kinases (MAPKs) or JNK phosphorylation. These findings demonstrate that scopoletin has anti-angiogenic properties that are manifested mainly through inhibiting migration and tube formation via downregulating ERK1/2 activation. Scopoletin may potentially be useful for angiogenesis treatment mediated disease and could serve as a structural basis for a screening of more potent synthetic analogues (Pan et al. 2009). Scopoletin might serve as a compound with a favorable activity against tumor cells, but some considerations have to be taken into account as the presence and activity, in the tumor cells, of proteins like NF-kB transcription factors, resistance factors for scopoletin treatment (Seo et al. 2016). Morever, Liu et al. (2001) observed that scopoletin inhibits PC3 cells (human prostate adenocarcinoma) proliferation and induced apoptosis. They used MTT assay and acid phosphatase activity (ACP) for cell proliferation, fluorescence microscopy to detect morphological changes and flow cytometry for cell cycle analysis. They observed that scopoletin not only induced a marked time and concentration dependent inhibition of cell proliferation, but also reduced the protein content, ACP level, and a marked decrease of cells in G2 state. Also, the typical morphological changes during apoptosis were observed. (Liu et al. 2001). Thus, both compounds could be useful as chemotherapeutic agents against skeletal muscle tumours if their 
antitumorigenic activities, as well as the molecular mechanism involved, are evaluated and scientifically proven using a suitable tumour model.

\section{Acknowledgments}

This research was supported by grant from the Consejo Nacional de Investigaciones Científicas y Técnicas (CONICET), PIP11220110100544; Comisión de Investigaciones Científicas (CIC) and Universidad Nacional del Sur (UNS), PGI 24/ Q071. LP, AV and LM are researcher members of CONICET; MBF is research member of CIC, FM thank the CONICET for a doctoral fellowship.

\section{References}

Berenman JC \& Wiener ES (2000) Issues in the local control of rhabdomyosarcoma. Medical and Pediatric Oncology 35: 104-109.

Bordoloi M, Saikia S, Bordoloi PK, Kolita B, Dutta PP, Bhuyan PD, Dutta SC \& Rao PG (2017) Isolation, characterization and antifungal activity of very long chain alkane derivatives from Cinnamomum obtusifolium, Elaeocarpus lanceifolius and Baccaurea sapida. Journal of Molecular Structure 1142: 200-210.

Donaldson SS, Meza J, Breneman JC, Crist WM, Laurie F, Qualman SJ \& Wharam M (2001) Results from the irs-iv randomized trial of Hyperfractionated radiotherapy in children with rhabdomyosarcoma - a report from the irsg. International Journal of Radiation Oncology, Biology, Physics 51: 718-728.

Donaldson SS \& Anderson JR (2005) Rhabdomyosarcoma: Many similarities, a few philosophical differences. Journal of Clinical Oncology 23: 2586-2587.

Dutta S, Mahalanobish S, Saha S, Ghosh S \& Sil PC (2019) Natural products: an upcoming therapeutic approach to cancer. Food and Chemical Toxicology 128: $240-255$.

Falasca S \& Ulberich A (2011) La maleza Nicotiana glauca (Graham) como cultivo energético en sectores áridos y semiáridos de Argentina. Zonas Áridas 15: 148-168.

Granville DJ, Cassidy BA, Ruehlmann DO, Choy JC, Brenner C, Kroemer G, van Breemen C, Margaron P, Hunt DW \& McManus BM (2001) Mitochondrial release of apoptosis-inducing factor and cytochrome c during smooth muscle cell apoptosis. American Journal of Pathology 159: 305-311.

Gunderson LL, Tepper JE, Ang KK, Glatstein EJ, Halperin EC, Harris J, Lawton V, Martinez AA, Shaw EG \& Turrisi AT (2000) Clinical radiation oncology. Churchill Livingstone, London. 1296p.

Hettmer S \& Wagers AJ (2010) Uncovering the origins of rhabdomyosarcoma. Nature Medicine 16: 171-173.

Janakat S \& Al-Merie H (2002) Evaluation of hepatoprotective effect of Pistacia lentiscus,
Phillyrea latifolia and Nicotiana glauca. Journal of Ethnopharmacology 83: 135-138.

Ji J, Zhang L, Wang P, Mu YM, Zhu XY, Wu YY, Yu H, Zhang B, Chen SM \& Sun XZ (2005) Saturated free fatty acid, palmitic acid, induces apoptosis in fetal hepatocytes in culture. Experimental and Toxicologic Pathology 56: 369-376.

Khan MU \& Hossain S (2015) Scopoletin and $\beta$-sitosterol glucoside from roots of Ipomoea digitata. Journal of Pharmacognosy and Phytochemistry 4: 5-7.

Liu XL, Zhang L, Fu XL, Chen K \& Qian BC (2001) Effect of scopoletin on PC3 cell proliferation and apoptosis. Acta Pharmacologica Sinica 22: 929-933.

Malempati S \& Hawkins DS (2012) Rhabdomyosarcoma: review of the children's oncology group (COG) softtissue sarcoma committee experience and rationale for current COG studies. Pediatric Blood \& Cancer 59: 5-10.

Mansoori B, Mohammadi A, Doustvandi MA, Mohammadnejad F, Kamari F, Gjerstorff MF, Baradaran B \& Hamblin MR (2019) Photodynamic therapy for cancer: role of natural products. Photodiagnosis and Photodynamic Therapy 26: 395-404.

Mukherjee AK, Basu S, Sarkar N \& Ghosh AC (2001) Advances in cancer therapy with plant based natural products. Current Medicinal Chemistry 8: 14671486.

Musso F, Lincor D, Vasconsuelo A, Pronsato L, Faraoni B \& Milanesi L (2019) Adverse effects in skeletal muscle following the medicinal use of Nicotiana glauca. Biological and Pharmaceutical Bulletin 42: 671-679.

Ognjanovic S, Linabery AM, Charbonneau B \& Ross JA (2009) Trends in childhood rhabdomyosarcoma incidence and survival in the United States (19752005). Cancer 115: 4218-4226.

Ouyang L, Luo Y, Tian M, Zhang SY, Lu R, Wang JH, Kasimu R \& Li X (2014) Plant natural products: from traditional compounds to new emerging drugs in cancer therapy. Cell Proliferation 47: 506-515.

Pan R, Dai Y, Yang J, Li Y, Yao X \& Xia Y (2009) Antiangiogenic potential of scopoletin is associated with the inhibition of ERK1/2 activation. Drug Development Research 70: 214-219.

Park EJ, Lee AY, Park S, Kim JH \& Cho MH (2014) Multiple pathways are involved in palmitic acidinduced toxicity. Food and Chemical Toxicology 67: 26-34.

Petit V, Boyer B, Lentz D, Turner CE, Thiery JP \& Vallés AM (2000) Phosphorylation of tyrosine residues 31 and 118 on paxillin regulates cell migration through an association with Crk in Nbt-II cells. The Journal of Cell Biology 148: 957-970.

Seo EJ, Saeed M, Law BYK, Wu AG, Kadioglu O, Greten HJ \& Efferth T (2016) Pharmacogenomics of scopoletin in tumor cells. Molecules 21: 496-519.

Stevens MCG, Rey A, Bouvet N, Ellershaw C, Flamant 
F, Habrand JL, Marsden HB, Martelli H, Sanchez de Toledo J, Spicer RD, Spooner D, Terrier-Lacombe MJ, van Unnik A \& Oberlin O (2005) Treatment of nonmetastatic rhabdomyosarcoma in childhood and adolescence: third study of the international Society of Paediatric Oncology-SIOP malignant mesenchymal tumor 89 . Journal of Clinical Oncology 23: 2618-2628.

Susin SA, Daugas E, Ravagnan L, Samejima K, Zamzami N, Loeffler M, Costantini P, Ferri KF, Irinopoulou T, Prevost MC, Brothers G, Mak TW, Penninger J, Ernshaw WC \& Kroemer G (2000) Two distinct pathways leading to nuclear apoptosis. Journal of Experimental Medicine 192: 571-580.

Taatjes DJ, Sobel BE \& Budd RC (2008) Morphological and cytochemical determination of cell death by apoptosis. Histochemistry and Cell Biollogy 129: 33-43.

Tabana YM, Hassan LEA, Ahamed MBK, Dahham SS, Iqbal MA, Saeed MAA, Khan SS, Sandai D, Majid ASA, Oon CE \& Majid AMSA (2016) Scopoletin, an active principle of tree tobacco (Nicotiana glauca) inhibits human tumor vascularization in xenograft models and modulates ERK1, VEGF-A, and FGF-2 in computer model. Microvascular Research 107: 17-33.
Torres-Nagera MA, López-López LLI, De La CruzGalicia G \& Silva-Belmares SY (2013) Mexican Solanaceae: a source of new pharmacologic agents. Revista Científica de la Universidad Autónoma de Coahuila 5: 27-32.

Shah VV, Shah ND \& Patrekar PV (2013) Medicinal plants from Solanaceae family. Research Journal of Pharmacy and Technology 6: 143-151.

Yadav R, Rathi M, Pednekar A \& Rewachandani Y (2016) A detailed review on Solanaceae family. European Journal of Pharmaceutical and Medical Research 3: 369-378.

Young JL, Ries DLG, Silverberg E, Horm JW \& Miller RW (1986) Cancer incidence, survival, and mortality for children younger than age 15 years. Cancer 58: 598-602.

Yuan Q, Zhao Q, Wang F, Zhang H, Chen ZJ, Wang J, Wang Z, Du Z, Ling EA, Liu Q \& Hao A (2013) Palmitic acid increases apoptosis of neural stem cells via activating c-Jun N-terminal kinase. Stem Cell Research 10: 257-266.

Zhao JW, Chen DS, Deng CS, Wang Q, Zhu1 W \& Lin L (2017) Evaluation of anti-inflammatory activity of compounds isolated from the rhizome of Ophiopogon japonicas. BMC Complementary and Alternative Medicine 17: 1-12. 